Pucara, $\mathrm{N}^{\circ} 29,147-167,2018$

https://publicaciones.ucuenca.edu.ec/ojs/index.php/pucara/issue/archive

ISSNe 2661-6912

\title{
Writing groups in Ecuador as support for academics on the road to publication
}

\section{Grupos de escritura en el Ecuador para el apoyo a académicos en su camino a la publicación \\ Grupos de redação no Equador para apoiar acadê- micos no caminho da publicação}

\section{Elisabeth Rodas Brosam}

Universidad de Cuenca, Ecuador

E-mail: elisabeth.rodas@ucuenca.edu.ec

\section{Laura Colombo}

CONICET, Instituto de Lingüística de la Universidad de Buenos Aires, Argentina

E-mail: laura.colombo@conicet.gov.ar

\section{Abstract}

Writing groups where authors get constructive feedback to improve their drafts are quite innovative in South America, especially for those not used to sharing their work in progress with academic readers, even more so when texts are produced in English as a second language. This paper presents the experience of a writing group in English which took place at a public Ecuadorian university. The participants revised and sent for publication a conference paper. To determine the usefulness of this initiative, group meetings were recorded, a short anonymous survey was administered, and a semi-structured focus group was conducted with 
the participants. Results show that, in line with previous research, this writing group presented benefits to help support academics on the road to publication such as experiencing and learning how to give and receive written feedback and learning literacy practices in a situated manner through dialogue.

Key words: writing groups, publishing, teacher development, second language writers

\section{Resumen}

Grupos de escritura donde los autores reciben feedback constructivo para mejorar sus textos son bastante novedosos en América Latina, especialmente para aquellos que no acostumbran compartir su trabajo en progreso con lectores académicos; y más si es que los textos son escritos en inglés como segundo idioma. Este trabajo presenta la experiencia de un grupo de escritura en inglés que tuvo lugar en una universidad pública ecuatoriana. Los participantes revisaron y enviaron a ser publicado una ponencia. Para determinar la utilidad del círculo, las sesiones de trabajo fueron grabadas para su análisis, se administró una encuesta corta, y se mantuvo un grupo focal semi-estructurado con los participantes. Los resultados muestran que, de acuerdo a la literatura, los grupos de escritura presentan beneficios para dar apoyo a los académicos en su camino a la publicación, tales como experimentar el dar y recibir feedback y el aprender las prácticas letradas de manera situada por medio del diálogo.

Palabras clave: círculos de escritura, publicación, desarrollo docente, escritores de segunda lengua

\section{Resumo}

Os grupos de escritores em que os autores obtêm feedback construtivo para melhorar seus rascunhos são bastante inovadores na América do Sul, especialmente para aqueles que costumavam compartilhar seu trabalho com os leitores acadêmicos, ainda mais quando os textos são produzidos em inglês como segunda língua. Este artigo apresenta a experiência de um grupo de escrita em inglês, realizado em uma universidade pública equatoriana. Os participantes revisaram e enviaram para publicação em um documento de conferência. Para determinar a utilidade do círculo, as sessões de trabalho foram registradas para análise, realizou-se uma breve pesquisa e um grupo focal foi mantido com os membros do grupo de pesquisa. Os resultados mostram que, de acordo com a literatura, os grupos de redação apresentam três benefícios fundamentais para apoiar os estudiosos no caminho da sua publicação, como experimentar e aprender como dar e receber feedback por escrito e aprender práticas de alfabetização em um diálogo menos estruturado.

Palavras chave: grupos de escritores, publicação, desenvolvimiento de profesores, escritores de segunda língua

\section{$* * *$}

\section{Introduction ${ }^{20}$}

In most countries, university professors are expected to conduct research and publish besides teaching particular courses in their field of study (Lee, 2013; Nygaard, 2015). This is related to the fact that university as well as

20 Este trabajo forma parte del Proyecto PICT 2014 financiado por la Agencia Nacional de Promoción Científica y Técnica de Argentina del cual es integrante la segunda autora. 
faculty performance is usuallymeasured through publication rates (McGrail, Rickard, \& Jones, 2006). Actually, for tenured professors, publication is generally tied to promotion or to the attainment of research grants, and for those new to the higher education environment, it can constitute a means of becoming a member of specific discourse communities. Thus, professors are confronted with the need to write academic genres (e.g., research articles and conference papers) for which they might not have been prepared (Antoniou \& Moriarty, 2008; Boud and Lee, 1999). This lack of preparation is often the case because writing for publication is mistakenly understood as something that academics already know how to do and need little to no guidance in developing research and writing skills (Blaxter, Hughes, \& Tight, 1998; Thomson \& Kamler, 2010).

Another important consideration is that if academics' first language is not English, they seem to be further challenged given its dominance in the publication world. These "geopolitics of academic writing" (Canagarajah, 2002) frequently place non-English speakers at a disadvantage (Bazerman, Keranen, \& Encinas Prudencio, 2012; Curry \& Lillis, 2007; Kirkpatrick, 2010; Ortiz, 2009). In fact, it has been noted that publications in other languages besides English do not have the same impact factor because they are not cited as often, and thus are not as widely read as those in English (Van Leeuwen, Moed, Tussen, Visser, \& Van Raan, 2001). Even if it could be argued that "citations are a shallow measure of research quality or impact" (Lillis \& Curry, 2010: 15), the need to write in English continues to create pressure for academics.

Some universities, mainly in North America and Europe, have made provisions to address the issue of teacher development in the area of research writing through different types of interventions such as writing workshops, writing tutorials, and writing groups (McGrail et al., 2006). Nevertheless, in most institutions this has been more often than not a neglected area (Boud \& Lee, 1999; Gómez Nashiki, Jiménez-García, \& Moreles Vázquez, 2014; Kwan, 2010; McGrail et al., 2006).
In the case of Latin America, in the last decades there has been an increase in research regarding writing and reading in different academic areas, focusing mainly on student writing at the secondary and university level (Navarro et al., 2016; Navarro, 2017). Interventions in behalf of the development of professors' academic and professional writing have not been a priority and thus are uncommon. As a matter of fact, academic writing or writing for publication initiatives in most Latin American universities are offered at the postgraduate level (Carlino, 2015; Colombo, 2013), with few of them directed at faculty development. When the latter occurs, institutions usually offer workshops or seminars but do not include them as part of professors' working hours. As a result, it seems that most universities demand professors to publish but do not openly support this activity (Narváez, 2010). Furthermore, if these initiatives aimed at teaching writing for publication are uncommon, even less frequent are those aimed at writing in a second language. As a consequence, researchers are left alone and have sole responsibility for learning to participate in disciplinary conversations in English (Englander, 2009). Thus, this situation continues to place non-native English speaking academics at a disadvantage.

Considering these challenges, the reading and writing program of one of the main public universities in Ecuador had as one of its objectives to strengthen the practice of academic and scientific writing at the university for students and professors. One of the initiatives put forth for this purpose consisted of writing groups as a tool to accompany professors transition from only teaching to teaching and researching. This paper analyzes this initiative born of an international collaboration (Ecuador-Argentina) between the two authors: starting a writing group with professors who needed to finish a conference paper in English as a second language. The first author was a member of the Academic Reading and Writing Program and acted as coordinator of the writing group, and the second author, who had experience implementing and researching writing groups, acted as a consultant. 
In the following sections, we first offer a description of writing groups and a brief account, based on previous research, of the benefits associated with them. Then, we present the experience carried out at the Ecuadorian university, followed by preliminary results of its implementation. Finally, we conclude with some considerations for the organization of future similar initiatives.

\section{Writing groups and the situated learning of literacy practices}

Writing groups provide a space where writers get together to provide constructive feedback on each other's drafts before submitting them for publication. As such, they have a long trajectory, especially in Englishspeaking environments (Gere,1987). However, their use in South American universities is still infrequent (Colombo \& Carlino, 2015). Although there are other types of interventions whose purpose is to increase the number of publications at the university level, three benefits of writing groups are highlighted that make them an interesting option.

First, writing groups offer a first-hand experience in the scholarly practice of giving and receiving feedback from peers in a safe environment (Boud \& Lee, 1999). Becoming used to peer feedback is a key social practice in the scientific community (Carlino, 2008, 2015; Colombo, 2013; Kumar \& Aitchison, 2017; among others) since prior to their acceptance, articles and conference papers are usually peer reviewed. Once published, scientific texts also come under the scrutiny and commentary of other community members. Nevertheless, peer feedback is a practice that is barely taught and, unfortunately, is usually learned through trial and error (Boud \& Molloy, 2012). Participating in a writing group gives academics the benefit of becoming used to readers' critical comments and of learning how to evaluate and offer constructive feedback to peers. In this sense, they can constitute a friendly arena where writers can enact and learn these practices that commonly take part in the publication world (Colombo, 2013; McGrail et al., 2006).
Additionally, by having preliminary readers, writing group members are also faced from the very beginning of their writing process with the need to consider their audience, another key element in academic and scientific writing. Learning to consider the reader is of utmost importance since knowledge of the needs and interests of the audience affects the content of the text (Swales \& Feak, 2004). Furthermore, instead of being an isolated activity, writing is viewed as an exchange between writer and reader, through the understanding of the rhetorical situation, an awareness of social context, and the expectations this exchange creates (Hyland, 2016).

Second, writing groups work in tandem with academics' need to have a higher writing production (Galligan et al., 2003). Through the organization of the group, members establish schedules, are accountable for giving feedback to each other on a weekly or bi-monthly basis, and are expected to maintain a commitment to writing until finishing a specific text, all of which helps to create and maintain the habit of frequent writing. Along these lines, it has been noted that where writing groups have been used to support academics' writing, this type of intervention has been better at helping to increase publication rates as well as the quality of the writing (Colombo \& Carlino, 2015; McGrail et al., 2006).

Third, writing groups support the idea that writing is not a solitary endeavor, but it entails the construction of knowledge through interaction with others (Aitchison, 2003; Van der Linden \& Renshaw, 2010). By being part of these groups, academics can learn and develop as writers of specific academic-scientific genres (Swales, 1990). The exchange of ideas and opinions with other participants can lead to making more explicit and thus manageable the interpretations and assumptions of readers from different scientific communities, the expected structure of texts, and the common linguistic devices used. Based on this, members of the group can make the necessary adjustments to improve their writing. In this sense, dialogue can lead to learning since by talking and exchanging ideas with others, meaning is negotiated and jointly 
constructed (Dysthe, Bernhardt, \& Esbjorn, 2013; Wells, 1990, 2007). This supports the belief that the construction of knowledge does not only happen through the writing of draft texts, but also through the interaction among members of the group, who each bring different perspectives and levels of experience that can benefit everyone (Aitchison, Kamler, \& Lee 2010; Dysthe, 1996).

The aforementioned characteristics of writing groups suggest that they are aligned with a situated framework for the teaching and learning of scholarly writing practices (Colombo, 2012). The situated learning theory (Lave \& Wenger, 1991) proposes that people learn by fulfilling activities which are peripheral but productive and thus grant newcomers the opportunity to explore viewpoints while getting involved in various social relations in the community. In effect, participating in writing groups allows members to interact with others while facing real writing tasks (i.e., legitimate publication practices) in specific disciplinary fields (i.e., disciplinary communities of practice). Therefore, the joint revision of texts allows academic writers to negotiate in a low-stake environment how to participate in disciplinary communities through written communication. This pedagogical potential of writing groups led us to propose it as a viable option to help fulfill one of the Academic Reading and Writing Program's objectives: strengthen the practice of academic and scientific writing at the University.

\section{The writing group experience}

The writing group experience analyzed here was carried out in one of the main public universities of the Ecuadorian Andes in 2016 and it was sponsored by its Academic Reading and Writing Program as a means to support scientific writing for publication in English. The group was coordinated by one of the authors of this paper and participation was voluntary. Two research groups from the Department of English Language and Literature were interested in participating; however, one of them decided not to due to time constraints and other obligations. The other group participated in this initiative since it needed to finish a text in English for publication.

Before the first group meeting, several emails were exchanged with the four participants and an online tool was chosen as a means to share the group's draft and other relevant documents, such as a calendar to determine the best time to meet and a document that suggested different areas that needed to be agreed upon (e.g., meeting place and time, sections to be reviewed, etc.). Concurrently with these preparation activities, the coordinator in Ecuador exchanged information and received suggestions on the formation of the writing group from the co-author of this paper in Argentina, based on her experience implementing this type of pedagogical initiative.

Typically, in a writing group each participant brings his or her own writing and thus there are as many drafts as participants. In this case, however, all the participants except the coordinator were authoring the same paper. As a result, the text only had one source of external peer feedback, instead of two or three as it is the case in most writing groups. Despite this, the initiative proceeded as the ultimate goal was to support the writing and publishing of scientific texts, in general.

The English text to be commented was a conference paper, meant to be published in a conference's proceedings. Since participants had a complete first draft and the deadline for presenting the paper was close, one-hour meetings were held once a week. The draft was reviewed before each meeting and comments were shared orally on the scheduled day and time. Each meeting focused on a specific section of the paper; thus for the first meeting participants worked on the introduction, the second meeting on the methodology, the third meeting on the results, and for the fourth meeting they reviewed the final version of the paper. The 
discussion and the conclusion sections of the paper were not reviewed in a group session, but the feedback for these sections was shared through the online tool before the last meeting.

Since the members of the group as well as the coordinator shared the same field of study in English, it was agreed that all meetings would be held in this language to facilitate comments and suggestions about the draft, and they were recorded with the participants' consent. In addition to the session recordings, printed and electronic documents were collected for analysis. Of the four members of the research group, two of them attended the writing group's meetings consistently, with the other two missing at least one of the meetings due to other university-related responsibilities. After the fourth session, once the text was completely reviewed, the writing group was concluded as it had achieved the purpose for which it had originally been created: to provide support to faculty to advance and finish a publication project.

\section{Results}

Even though the writing group described here had only one text to receive feedback and only one reader, the experience did provide results that make this type of initiative positive to accompany academics' need to write at the university level. To analyze this first implementation, a focus group was held to gather information about the members' experience in the writing group. Additionally, a short, anonymous survey was sent to the participants five months after the initiative ended. The questionnaire gathered information about their experience receiving feedback, their perception of the writing group as a means to improve their writing skills and habits, as well as their feelings about presenting their text for publication after having been previously reviewed by an outside reader. In line with previous research and based on the data gathered, participants agreed that the writing group was beneficial and it provided opportunities to develop the three aforementioned aspects that facilitate learning academic writing practices.
The first aspect, the giving of feedback through a safe and friendly environment, was mentioned in the last meeting where one of the participants asserted: "I feel very comfortable working with you ... and receive all your feedback and it is so direct, so face to face so that the environment also, I think, it's very positive." As this quote shows, the writing group created a space where the members could discuss their ideas and receive comments on their writing without feeling attacked or exposed. In the same vein, another member of the research group expressed, "I feel good when I work in this way. So for me everything is positive." With the other participants agreeing, it seems that in this case, as in the experiences reported by the literature, the writing group provided a secure space where writers engage in the receiving and giving of feedback, a useful scholarly practice. Through the survey, the respondents stated that what they enjoyed most about the writing group was that each meeting provided "feedback that was very relevant to the text," and "how the feedback was given" was regarded as positive. In general, criticism, even when it is meant as constructive feedback, is usually hard to receive; thus, this first-hand experience gained by the participants in the writing group provided them with a glimpse of the peer interaction common in academic environments, such as the peer review process.

At the same time, peer feedback was the means by which the reader's perspective was transmitted to the authors, thus having participants experience this important aspect of scientific writing. In this sense, the comments shared orally during the writing group meetings provided its members with the opportunity to envision their audience, often a difficult task for novice writers, by examining its possible expectations of the text's structure and content, what Hyland (2016) considers the reading approach to writing. This was possible thanks to the intervention of the coordinator, who guided participants on how to give feedback and asked "reflective questions" (Hyatt, 2005) to better understand the research that had been done and how this was transmitted in the text itself. Through these types of questions, the purpose was to have the authors consider not only the content but also the language used and how 
it could be modified in order to make it understood by an outside reader. The respondents to the survey indicated that "having the viewpoint of another person allowed me to see things that, as the author, I couldn't have seen," as well as "listening to the opinion of another person about my work" was the most useful aspect of the writing group. Once again, having the opportunity to access readers' interpretations of a text before sending it for evaluation was a valuable tool since it allowed the authors to anticipate some criticisms and improve their draft.

In this writing group, the second benefit of this type of initiative was met by reviewing the whole text before sending it for publication. The weekly meetings structured the writing process and kept members accountable for devoting time to this task. Additionally, it allowed authors to experience writing as an iterative process where usually more than one revision is needed once you have a complete draft. The regular encounters, then, compelled the participants not only to devote time reviewing the text but also to break down the reviewing activity into more manageable and feasible tasks. As a result, at the end of the meetings, the text had been commented on, suggestions received and considered, and changes made as the research group deemed necessary. The conference paper was completed and sent to be evaluated to be part of the conference proceedings, as it was confirmed later via email to the coordinator. The participants felt more confident about sending their paper for publication once it had already been reviewed inside the writing group, as survey results indicated.

Finally, another benefit of writing groups is working with others to build knowledge (Aitchison, 2003; Van der Linden \& Renshaw, 2010). In this regard, the usefulness of the writing group is expressed thusly by a member during the last meeting: "The first time we wrote it, we said 'it is fine, we are okay.' And then, after going through this whole process and looking at all the changes we have made, we realized: no, no. You definitely need someone else's perspective; otherwise, there is no way something like this can be accomplished." Through the different questions asked by the coordinator to clarify sections of the text and the group discussions that these questions triggered, the authors were able to view their writing and the ideas conveyed through it from a different perspective. Additionally, through dialogue, they clarified ideas and considered other ways to more clearly express them on paper.

Of special importance in this specific group was the fact that all the members were English professors, including the coordinator, as mentioned earlier. This created an environment where it was possible to collaborate with each other in order to clarify the use of different terms, expressions, and organizational and structural questions in this second language. Thus, this particular situation helped to directly address the task of scholarly writing in another language to meet standard conventions.

\section{Conclusion}

This first experience of a writing group yielded several positive conclusions. First, it provided guidelines to consider when organizing new writing groups at the university level, especially the importance of having more than one reader. Although the feedback provided during the group meetings to a text co-authored by four professors was relevant and beneficial to improve the draft, as indicated by the participants, comments and suggestions from more than one reader would have presented richer feedback and a more varied audience.

Second, this experience has contributed with important insights about how feedback could be shared and made available. In this writing group, feedback was mainly shared orally, with written comments and suggestions later shared through an online tool. However, based on comments from the members, the coordinator considered that not all feedback given during the meetings could be assimilated in detail or written down as it happened; feedback was generally expanded on and discussion of sections provided the research group a different perspective of their own work that went beyond short annotations on 
the margins of the text. These oral interchanges were important since they allowed the joint construction of knowledge and the negotiation of meaning, something that probably would not have happened if the reader had given only written feedback. This led to the reflection that comments need to be shared in different ways in future writing groups, by using the technology that currently makes group collaboration much easier. One of these ways would be to share the audio recordings with the members of the writing group, making them available for future review. Another option would be to share written feedback through an online collaboration tool before each meeting, thus having all comments ready for discussion and expansion, if needed, during faceto-face interactions.

Third, as all the members were users of the English language, the writing group provided a means to reaffirm and consolidate the use of this language in academic writing, considering the syntax, lexis, and organization to best convey the content of the article as it had been intended and thus better fulfill the specific discourse community demands (Lave \& Wenger, 1991). Additionally, working on an authentic use of the language through the writing of a real text (Roberts \& Banegas, 2018), a conference paper to be submitted for evaluation, allowed members to access legitimate peripheral participation (Lave \& Wenger, 1991) in literacy practices. It also made explicit the fact that learning is a continuous process in an academic's life (Flowerdew, 2000).

As a whole, based on a first analysis of the sessions, this initial experience of a writing group instituted through the Academic Reading and Writing Program at a public Ecuadorian university can be considered positive. Not only did the writing group come to be, but it also produced results, with a finished paper that was consequently sent, evaluated and accepted for publication. It also provided valuable insights for the coordinator and the consultant for the implementation of future writing groups. This first experience can serve as inspiration for similar pedagogical initiatives in other contexts. So far, it seems that writing groups have the potential to contribute in positive ways to the development of professors' academic and scientific writing skills, considering that becoming a mature and effective writer is a lifelong process (Bazerman, 2013). Since academics' need to become involved in literacy practices will no doubt continue to increase, institutions should provide as well as maintain the tools to meet this challenge. 


\section{References}

Aitchison, C. (2003). Thesis writing circles. Hong Kong Journal of Applied Linguistics, 8(2), 97-115.

Aitchison, C., Kamler, B., \& Lee, A. (2010). Publishing pedagogies for the doctorate and beyond. New York: Routledge.

Antoniou, M., \& Moriarty, J. (2008). What can academic writers learn from creative writers? Developing guidance and support for lecturers in Higher Education. Teaching in Higher Education, 13(2), 157-167.

Bazerman, C. (2013). Understanding the lifelong journey of writing development / Comprendiendo un viaje que dura toda la vida: La evolución de la escritura. Infancia y Aprendizaje, 36(4) 421-441.

Bazerman, C., Keranen, N., \& Encinas Prudencio, F. (2012). Facilitated immersion at a distance in second language scientific writing. In M. Castelló \& C. Donahue (Eds.), University Writing. Selves and Texts in Academic Societies (pp. 235-248). Bingley: Emerald Group Publishing Limited.

Blaxter, L., Hughes, C., \& Tight, M. (1998). Writing on academic careers. Studies in Higher Education, 23(3), 281.

Boud, D., \& Lee, A. (1999). Promoting research development through writing groups. Paper presented at the Australian Association for Research in Education Conference, Melbourne, Australia. Retrieved February, 2012, from www.aare.edu.au

Boud, D., \& Molloy, E. (2012). Rethinking models of feedback for learning: The challenge of design. Assessment \& Evaluation in Higher Education, 38(6), 698-712.
Canagarajah, A. S. (2002). A geopolitics of academic writing. Pittsburgh, PA.: University of Pittsburgh Press.

Carlino, P. (2008). Revisión entre pares en la formación de posgrado. Lectura y Vida, 29(2), 20-31. Available at https://sites.google. com/site/jornadasgiceolem/posgrado.

Carlino, P. (2015). Revisión entre pares: Una práctica social que los posgrados deberían enseñar. Espaço Pedagogico, 22(1), 9-29.

Colombo, L. (2012). Escritura de posgrado y aprendizaje situado. In Facultad de Psicología de la Universidad de Buenos Aires (Ed.), Memorias del IV Congreso Internacional de Investigación y Práctica Profesional en Psicología - XIX Jornadas de Investigación - VIII Encuentro de Investigadores en Psicología del MERCOSUR [en CD] (Vol. 1, pp. 82-85). Buenos Aires, Argentina: Ediciones de la Facultad de Psicología - Universidad de Buenos Aires. Available at https://sites.google.com/site/ jornadasgiceolem/posgrado.

Colombo, L. (2013). Una experiencia pedagógica con grupos de escritura en el posgrado. Aula Universitaria, 15, 61-68. Available at http://bibliotecavirtual.unl.edu.ar/publicaciones/index.php/ AulaUniversitaria/article/view/4368/6643.

Colombo, L., \& Carlino, P. (2015). Grupos para el desarrollo de la escritura científico-académica: Una revisión de trabajos anglosajones. Lenguaje, 43(1), 13-34. Available at http://revistalenguaje. univalle.edu.co/index.php/Lenguaje/article/view/3276.

Curry, M. J., \& Lillis, T. (2007). The dominance of English in global scholarly publishing. International Higher Education, 46, 6-7.

Dysthe, O. (1996). The multivoiced classroom. Written Communication, 13(3), 385-425. 
Dysthe, O., Bernhardt, N., \& Esbjorn, L. (2013). Enseñanza basada en el diálogo: El museo de arte como espacio de aprendizaje. Dinamarca: Skoletjenesten \& Fagbokforlaget.

Englander, K. (2009). El mundo globalizado de las publicaciones científicas en inglés: Un enfoque analítico para comprender a los científicos multilingües. Discurso \& Sociedad, 3(1), 90-118.

Flowerdew, J. (2000). Discourse Community, Legitimate Peripheral Participation, and the Nonnative-English-Speaking Scholar. TESOL Quarterly, 34(1), 127-150.

Galligan, L., Cretchley, P., George, L., Martin, K., McDonald, J., \& Rankin, J. (2003). Evolution and emerging trends of university writing groups. Queensland Journal of Educational Research, $19(1), 28-41$

Gere, A. R. (1987). Writing groups: History, theory, and implications. Carbondale \& Edwardsville: Southern Illinois University Press.

Gómez Nashiki, A., Jiménez-García, S. A., \& Moreles Vázquez, J. (2014). Publicar en revistas científicas, recomendaciones de investigadores de ciencias sociales y humanidades. Revista Mexicana de Investigación Educativa, 19(60), 155-185.

Hyatt, D. F. (2005). 'Yes, a very good point!': A critical genre analysis of a corpus of feedback commentaries on Master of Education assignments. Teaching in Higher Education, 10(3), 339-353.

Hyland, K. (2016). Teaching and researching writing. (3rd ed.). New York/Abingdon: Routledge.

Kirkpatrick, A. (2010). The Routledge handbook of world Englishes. New York: Routledge.
Kumar, V., \& Aitchison, C. (2017). Peer facilitated writing groups: a programmatic approach to doctoral student writing. Teaching in Higher Education, 23(3): 360-373.

Kwan, B. S. C. (2010). An investigation of instruction in research publishing offered in doctoral programs: The Hong Kong case. Higher Education, 59(1), 55-68.

Lave, J., \& Wenger, E. (1991). Situated learning: Legitimate peripheral participation. New York: Cambridge University Press.

Lee, I. (2013). Publish or perish: The myth and reality of academic publishing. Language teaching, 47(2), 1-12.

Lillis, T. \& Curry, M. J. (2010). Academic writing in a global context: The politics and practices of publishing in English. London: Routledge.

McGrail, M., Rickard, C., \& Jones, R. (2006). Publish or perish: A systematic review of interventions to increase academic publication rates. Higher Education Research \& Development, $25(1), 19-35$

Narváez, E. (2010). Escritura académica y formación de docentes universitarios. Pedagogía y Saberes 33, 113-124.

Navarro, F. (2017). Estudios latinoamericanos de la escritura en educación superior y contextos profesionales: hacia la configuración de un campo disciplinar propio. Lenguas Modernas, 50, 9-14.

Navarro, F., Ávila Reyes, N., Tapia Ladino, M., Lopez Cristovão, V. L., Moritz, M. E. W., Narváez Cardona, E., \& Bazerman, C. (2016). Panorama histórico y contrastivo de los estudios sobre lectura y escritura en educación superior publicados en América Latina. Revista Signos, 49(S1), 100-126. 
Nygaard, L. P. (2015). Publishing and perishing: An academic literacies framework for investigating research productivity. Studies in Higher Education, 42(3), 519-532.

Ortiz, R. (2009). La supremacía del inglés en las ciencias sociales (T. Arijón, Trans.). Buenos Aires: Siglo XXI.

Roberts, G., \& Banegas, D.L. (2018). Writing beyond the classroom: Insights on authenticity and motivation. Argentinian Journal of Applied Linguistics, 6(2), 33-41. Available at http://www.faapi. org.ar/ajal/issues/602/RobertsBanegas.pdf.

Swales, J. (1990). Genre analysis: English in academic and research settings. Cambridge University Press.

Swales, J. M., \& Feak, C. B. (2004). Academic writing for graduate students: Essential tasks and skills (2nd ed.). Ann Arbor, MI: University of Michigan Press.

Thomson, P., \& Kamler, B. (2010). It's been said before and we'll say it again-research is writing. In P. Thomson \& M. Walker (Eds.), The Routledge Doctoral Student's Companion: Getting to Grips with Research in Education and the Social Sciences (pp. 149160). London and New York: Routledge.

Van der Linden, J., \& Renshaw, P. (Eds.). (2010). Dialogic learning: Shifting perspectives to learning, instruction and teaching. New York: Kluwer.

Van Leeuwen, T. N., Moed, H. F., Tussen, R. J., Visser, M. S., \& Van Raan, A. F. (2001). Language Biases in the Coverage of the Science Citation Index and its Consequences for International Comparisons of National Research Performance. Scientometrics, $51,335-346$.
Wells, G. (1990). Talk about text: Where literacy is learned and taught. Curriculum Inquiry, 20(4), 369-405.

Wells, G. (2007). Semiotic mediation, dialogue and the construction of knowledge. Commentary. Human Development, 50(5), $244-$ 285. 